\title{
PENGEMBANGAN AKTIVITAS WISATA DI TAMAN HUTAN RAYA IR. H. DJUANDA BANDUNG JAWA BARAT
}

\author{
Andi Moh. Rifiyan Arief \\ Program Studi Pariwisata Jurusan Ilmu Administasi \\ Fakultas Ilmu Sosial Dan Ilmu Politik Universitas Riau, Pekanbaru \\ Email: the_ifans@yahoo.com
}

\begin{abstract}
Abstrak: Djuanda forest park based RIPPDA Prov. Jabar in 2005 is one tourist attraction that supports the development of mountainous nature of urban and tourist areas Bandung education. At this time, tourism activities in the forest park can be said Djuanda less varied and not utilize the full potensial optimaly. This is evident from the close of the management of some the activities alredy underway. Closing the management of this activity is not offset by the new tourist activities, which led to the visitors who come today are less likely to have the option of doing tourist activities. Related to the above, in support of the position Djuanda forest park as a tourist attraction mountainous landscape that supports the development of urban and tourist areas Bandung education is deemed necessary to carry out the development of tourism activities

Keywords: Innovation, potential optimaly, development of tourism activities
\end{abstract}

\section{PENDAHULUAN}

Kabupaten Bandung Provinsi Jawa Barat sedang mengembangkan sektor kepariwisataannya sebagai salah satu program pemerataan pembangunan daerah. Salah satu dari objek dan daya tarik wisata alam pegunungan di daerah ini adalah Taman Hutan Raya Ir. H. Djuanda (THR Djuanda) yang menjadi salah satu daya tarik wisata pegunungan yang mendukung pegembangan Kawasan Wisata Perkotaan dan Pendidikan Bandung (RIPPDA Prov. Jabar, 2005;VI-44).

Keterbatasan dukungan sarana dan prasarana penunjang merupakan salah satu permasalahan yang perlu mendapat perhatian, Taman Hutan Raya (THR) Djuanda berada di provinsi Jawa Barat tepatnya berada di kabupaten Bandung, dan merupakan Taman Hutan Raya pertama di Indonesia.Taman Hutan Raya Djuanda berada di bawah Dinas Kehutanan Provinsi Jawa Barat.Kawasan THR Djuanda merupakan area kawasanhutan dengan luas \pm 524 Ha berada pada ketinggian 750 - 1330 meter dpl. Kawasan ini cukup dekat dengan pusat kota Bandung yaitu berjarak lebih kurang $8 \mathrm{~km}$ dari pusat pemerintahan Kota Bandung.

Maka dari itu sesuai dengan fungsinya THR dapat dimanfaatkan untuk berbagai tujuan diantaranya sebagai wahana penelitian dan pengembangan ilmu pengetahuan serta pendidikan bagi masyarakat terkait dengan flora dan fauna serta ekosistemnya dalam wahana pelestarian budaya terkait dengan pariwisata maka THR Djuanda dimanfaatkan untuk tujuan kegiatan pariwisata dan rekreasi maka didukung dengan adanya PP No 18 tahun 1994 tentang Pengusahaan 
Pariwisata Alami di Zonasi THR dan Taman Wisata Alam yang berbunyi sebagai berikut: Taman Nasional, Taman Hutan dan Taman Wisata Alam yang merupakan kekayaan alam yang sangat tinggi nilainya perlu dijaga kelestariaannya dan dapat dimanfaatkan untuk kegiatan pariwisata.

THR Djuanda memiliki berbagai ragam daya tarik wisata antara lain pengembangan daya tarik rekreasi, pariwisata, koleksi flora, pengembangan ilmu pengetahuan, pendidikan dan memiliki berbagai fenomena alam seperti air terjun dan patahan, peninggalan sejarah seperti prasasti Goa Buatan serta artefak-artefak purba.

Berdasarkan gambaran taman hutan raya Djuanda dan pengembangan aktivitas wisatanya, maka tujuan dari penelitian ini adalah untuk melakukan pengembangan aktivitas wisata, baik peningkatan aktivitas wisata yang sudah berjalan maupun manambahkan yang kurang dalam menggali potensi daya tarik yang ada di THR Djuanda.

\section{METODE PENELITIAN}

Metode penelitian yang digunakan pada penelitian ini adalah metode penelitian deskriptif kualitatif yang dilakukan terhadap komponen-komponen terkait terhadap wisata THR Djuanda, dengan menggunakan analisis SWOT. Taman Hutan Raya Ir. H. Djuanda merupakan Taman Hutan Raya Pertama yang diresmikan dan merupkan satu dari 12 THR yang ada di wilayah Indonesia. Taman Hutan ini merupakan taman yang cukup strategis dari aksesibilitas dari pusat kota Bandung yang berjarak $\pm 8 \mathrm{~km}$. Terkait dengan upaya pemanfaatan kawasan, kegiatan pariwisata menjadi salah satu kegiatan yang dilakukan di THR Djuanda, sesuai dari fungsi Taman Hutan Raya.Kebijakan Pengembangan pariwisata THR Djuanda dipengaruhi kebijakan pengembangan pariwisata daerah. Adapun kebijakan yang mempengaruhi pengembangan pariwisata di THR Djuanda adalah antara lain kebijakan pengembangan pariwisata di Jawa Barat serta kebijakan pariwisata di Kota/Kabupaten Bandung. Gambaran umum kunjungan wisatawan ke objek wisata Kabupaten Bandung pada tahun 2012 adalah sebagai berikut:

Wisnus berjumlah 2.405.923 orang

Wisman berjumlah 57.433 orang

Data Dispar Kabupaten Bandung, 2013

Kunjungan wisatawan mancanegara dan domestik ke Kota Bandung tahun 2012 :

Wisnus berjumlah $\quad 1.837 .500$ orang

Wisman berjumlah $\quad 91.350$ orang

Data Dispar Kota Bandung, 2013 
Profil pengunjung THR Djuanda

Umur antara $17-40$ tahun

Pada tahun 2011 pengunjung 88.807 orang

Sumber: Manajemen THR Djuanda, 2013

Pemerintah dalam kebijakannya yang digunkaan sebagai landasan dalam kegiatan kepariwisataan di THR Djuanda mengacu kepada UU No 5 tahun 1990 tentang konservasi sumber daya alam hayati dan ekosistemnya, yang menyebutkan bahwa potensi yang terdapat di kawasan konservasi dapat dioptimumkan pendayagunaannya untuk kegiatan pariwisata alam dan rekreasi. Oleh sabab itu pemanfaatan atau pengusahaan pariwisata atau rekreasi sangat dimungkinkan dalam konteks THR Djuanda. Zona pemanfaatan dapat dilakukan melalui kegiatan:

1. Pemanfaatan kondisi lingkungan kawasan pelestarian alam yang dilakukan dengan tetap menjaga kelestarian fungsi kawasannya.

2. Pemanfaatan jenis tumbuhan dan satwa liar dilakukan dengan memperhatikan kelangsungan potensi, daya dukung dan keanekaragaman jenis tumbuhan dan satwa liar.

\section{HASIL DAN PEMBAHASAN}

Proses analisis yang dilakukan akan mencakup pada analisis kondisi fisik alam dan daya tarik wisata THR Djuanda, analisis pengembangan aktivitas wisata dan fasilitas wisata pendukung kegiatan wisata, analisis pengelolaan, serta analisis SWOT.

\section{Analisis Kondisi Fisisk Alam THR Djuanda}

Analisis elemen alam akan dianalisis melalui berbagai aspek yang dapat dipertimbangkan berdasarkan struktur berikut ini:

1. Geologi

Jenis tanah di THR Djuanda relatif peka terhadap erosi, tetapi memiliki kestabilan tanah yang relatif stabil.

2. Flora dan Fauna

Dengan ragam jenis tanaman yang ada. Selain itu, kawasan THR Djuanda memiliki pola vegetasi yang rapat di area hutan dan sedikit terbuka di area dekat dengan pintu masuk utama/ pemusatan pengunjung.

3. Hidrologi

THR Djuanda memiliki empat sumber air yang dapat dimanfaatkan yaitu sumber mata air, aliran air dari PAM, air dari kolam PLTA Bengkok dan aliran air sungai Cikapundung.

4. Klimatologi

Kondisi iklim kawasan THR Djuanda berkisar antara 18 derajat celcius sampai 24 derajat celcius yang merupakan perpaduan antara iklim perkotaan Bandung dengan iklim hutan pegunungan THR Djuanda. 
5. Estetika

Kualitas lingkungan kawasan THR Djuanda secara keseluruhan dapat dikatakan baik dengan bentang alam dan panoramanya yang indah, karena banyak terdapat banyak pepohonan/vegetasi.

6. Topografi

Kondisi topografi pada umumnya adalah miring bervariasi antara datar, agak curam sampai terjal. Dari kondisi topografi yang ada, maka kondisi tersebut akan sangat mempengaruhi variasi pengembangan aktivitas yang dilakukan.

7. Rintangan Fisiografik

Rintangan fisiografik seperti vegetasi atau hewan berbahaya/ mengganggu dapat mempengaruhi kepuasan berwisata pengunjung dan memberikan kesan tidak nyaman, atau dapat membahayakan pengunjung yang sedang melakukan aktivitasnya.

\section{Analisis Produk wisata THR Djuanda}

\section{Daya tarik Wisata/ Atraksi}

Untuk memudahkan analisis atraksi wisata yang berada di THR Djuanda ini, maka analisis ini akan dilakukan dengan cara menganalisis atraksi berdasarkan lokasinya, yaitu berdasarkan blok-blok yang sudah ditentukan pengelola, yaitu sebagai berikut:

a. Blok Pakar

1) Plaza Monumen Ir. H. Djuanda

Merupakan pelataran tempat berkumpul, berbahan dasar semen, dan terdapat patung Ir. H. Djuanda.

2) Goa Belanda

Goa Belanda sebagai atraksi wisata memiliki nilai sejarah/ historis yang tinggi yang menjadi salah satu daya tarik pengunjung. Dahulu goa Belanda dilengkapi lampu penerangan, tetapi sekarang sudah rusak dan tidak berfungsi lagi.

3) Goa Jepang

Goa Jepang juga memeiliki nilai sejarah yang tinggi yang dapat menjadi salah satu daya tarik bagi pengunjung. Goa ini juga dimanfaatkan oleh pengunjung untuk aktifitas penelusuran goa.

4) Arboretum

Merupakan area koleksi tanaman yg sudah dilengkapi fasilitas papan nama pohon. Arboretum ini biasanya dimanfaatkan oleh para siswa/pelajar yang datang untuk melakukan aktivitas pengamatan pohon/penelitian lapangan mengenai jenis-jenis tanaman serta menikmati panorama alam.

5) Kolam PLTA Bengkok

Terdapat fasilitas seperti shelter dan meja taman serta papan informasi disekitar area ini.

6) Area Curug Lalay

Di area ini terdapat fenomena air terjun, yang di kiri dan kanan area sungai menuju air terjun terdapat tebing vertikal 15 meter dari 
bebatuan, dimana ditempat ini terdapat juga sarang kelalawar, lokasi area ini berada di area perlindungan kawasan THR Djuanda.

b. Blok Maribaya

1) Curug Omas

Memiliki lokasi berdekatan dengan objek Wisata Air Panas Maribaya yang dikelola oleh Dinas Pariwisata Kab. Bandung.

2) Patahan Lembang

Berlokasi di blok Maribaya dekat dengan curug omas. Patahan lembang merupakan patahan dengan panorama alam yang indah.

c. Blok Curug Dago

1) Curug Dago

Merupakan air terjun dari sungai cikapundung yang terletak di blok curug dago yang terpisah dari pemukiman penduduk sekitar $1 \mathrm{Km}$ dari ujung selatan kawasan dago pakar.

2) Prasasti Thailand

Terletak di blok curug dago, batu ini cenderung tidak terawat dan memiliki kondisi yang kotor dan banyak vandalisme disekitarnya, sehingga resiko kerusakan pada daya tarik ini menjadi sangat besar.

\section{Sarana dan Prasarana}

Keberadaan fasilitas akan dianalisis berdasarkan jenisnya dan fungsi fasilitas tersebut sebagai penunjang aktivitas wisata di kawasan THR Djuanda, terkait keberadaannya dalam kawasan pelestarian alam.

Analisis sarana dan prasarana THR Djuanda sebagai berikut:

a. Sarana

1) Kios Makan Minum

Terdapat fasilitas makan dan minum dengan jenis kios makan mi num berjumlah 23 unit yang penempatannya tersebar di dalam kawasan.

2) Kantor Pengelola

Secara umum sudah memiliki kondisi cukup baik karena sudah terdapat fasilitas yang cukup lengkap seperti listrik dan komunikasi.

3) Fasilitas Keamanan

Fasilitas keamanan sudah tersedia dikawasan ini dengan adanya 2 unit pos keamanan yang terletak di dekat pintu masuk utama dan dekat dengan kantor pengelola dengan kondisi cukup baik dan terdapatnya petugas keamanan yang berjaga.

4) Fasilitas Ibadah

Fasilitas Musholah yang berjumlah 2 unit sudah cukup baik yaitu salah satu diperuntukkan bagi pengunjung yang lokasinya berdekatan dengan tempat parkir yang berada dalam kawasan.

5) Rumah Dinas

Sudah terdapat rumah dinas bagi karyawan berjumlah 5 unit, terletak dekat kantor pengelola, sehingga kesejahteraan karyawan sudah cukup diperhatikan oleh pihak pengelola. 
6) Information Center/ Pusat Informasi

Gedung pusat informasi kondisinya sudah cukup baik dan pada pusat informasi ini pengunjung bisa mendapatkan berbagai informasi mengenai THR Djuanda.

7) Panggung Terbuka

Panggung pertunjukan ini dibuat dengan bahan dasar semen dan lokasinya dekat dengan area plaza dengan kondisi cukup baik.

8) Meja Taman

Meja taman terbuat dari kayu yang ramah lingkungan menyatu dengan alam dan penempatannya cukup tersebar disekitar kawasan.

9) Papan Informasi/ Signage

Papan Informasi yang tersedia sudah cukup tersebar di dalam kawasan.

10) Rumah Flora dan Rumah Aklimatisasi

Kedua fasilitas ini memiliki jenis dan fungsi yang hampir serupa yaitu sebagai bangunan tempat mengoleksi tanaman, baik tanaman hias ataupun tanaman pohon yang terdiri dari dua unit bangunan.

11) Tempat Bermain Anak/ Children Playground

Tempat bermain anak ini berlokasi dekat dengan pusat kegiatan aktivitas dengan kondisi yang cukup baik.

12) Tempat Sampah

Penempatan tempat sampah di kawasan ini tersebar merata di seluruh kawasan.

13) Toilet

Fasilitas ini dilihat dari lokasi pengadaannya sudah cukup baik kareana tersebar di area pusat aktivitas pengunjung.

b. Prasarana

1) Sistem Pembuangan Limbah

Hasil limbah kawasan ini terdiri dari dua jenis yaitu limbah padat dan limbah cair. Pengelolaan limbah padat dilakukan dengan melakukan pembakaran di tempat pembuangan utama kawasan.

2) Sumber Daya Air Bersih

Kawasan ini memanfaatkan 2 sumber air bersih yaitu PAM Pakar yang jaraknya cukup dekat, dan dari sumber mata air setempat.

3) Sumber Daya Listrik

Pendistribusian sumber daya listrik yang diambil dari PLN ini, dilakukan melalui kabel listrik yang ditopang oleh tiang-tiang listrik yang berpusat dari area kantor pengelola (area pemusatan pengunjung) sampai dengan area goa Belanda.

3. Aksesibilitas

a. Jalan

Jalan inter-kawasan yang menghubungkan THR Djuanda dengan jalan utama berupa jalan kecamatan dengan bahan aspal hotmix dengan lebar 6 meter diamana hampir semua jenis kendaraan dapat melewati jalan ini,

b. Tempat Parkir 
THR Djuanda memiliki 2 tempat parkir kendaraan. Dilihat dari material ground cover-nya sudah cukup baik berupa aspal hotmix yang dapat menahan beban kendaraan cukup besar pada area parkir utama dekat dengan pintu masuk utama, serta bahan paving block pada area parkir dekat dengan kantor pengelola.

c. Pintu/loket masuk

Kawasan THR Djuanda memiliki empat unit pintu/loket masuk menuju kawasan, yaitu pintu gerbang satu/utama, yang lokasinya paling berdekatan dengan area parkir utama. Selanjutnya adalah pintu gerbang dua yang digunakan juga untuk masuknya kendaraan pengunjung, lalu pintu gerbang tiga yang khusus disediakan bagi pejalan kaki dengan berjalan kaki sejauh 200 meter melewati pemukiman penduduk dari jalan raya utama, serta pintu gerbang empat yang merupakan gerbang masuk kawasan dari arah ODTW Maribaya.

\section{A. Analisis Aktivitas Wisata THR Djuanda}

1. Aktivitas Wisata Aktual

Aktivitas wisata yang dapat dilakukan pengunjung berdasarkan kelompok aktivitas wisata adalah sebagai berikut:

a. Indoor activities

1) Mengamati koleksi yang ada di museum THR Djuanda

Pengunjung dapat memasuki museum ini secara bebas tanpa harus membayar lagi, dan bisa mengamati koleksi yang ada.

2) Mengamati tanaman hias di Rumah Flora

Dapat dilakukan pengamatan berbagai jenis tanaman hias yang ada di rumah flora, dimana tanaman-tanaman ini sudah diletakkan pada pot-pot tanaman di dalam bangunan pembibitan (rumah flora).

\section{b. Land based activities}

1) Photography

Aktivitas photography dilakukan di sekitar kawasan THR Djuanda secara bebas, kegiatan ini dapat dilakukan diseluruh area kawasan.

2) Mengamati Goa

Aktivitas ini cukup digemari oleh wisatawan yang datang ke THR Djuanda karena goa Belanda dan goa Jepang ini sudah cukup dikenal oleh kalangan pengunjung yang datang.

3) Mengamati Fenomena Alam

Aktivitas ini merupakan aktivitas pengunjung untuk mengagumi keindahan fenomena alam berupa air terjun dan fenomena patahan/tebing yang terdapat dikawasan ini.

4) Aktivitas mengamati flora dan fauna

Selain sambil belajar tentang alam dan lingkungan, pengujung juga sekaligus berekreasi menikmati alam sekitar yang diantaranya adalah mengamati pohon di arboretum.

5) Gathering/pertemuan di alam terbuka 
Aktivitas ini dilakukan oleh pengunjung yang datang secara berkelompok dengan tujuan untuk mengadakan acara bersamasama dengan background alam.

6) Berjalan di alam/jogging (jalur Pakar-Maribaya)

Aktivitas yang dilakukan adalah berjalan kaki/jogging dengan rute Pakar-Maribaya (kurang lebih $5 \mathrm{Km}$ ) menyusuri jalan setapak berbahan Paving block yang sudah disediakan.

7) Mountain Bike

Seperti halnya jogging, jalur jalan setapak Pakar-Maribaya juga dimanfaatkan oleh pengunjung untuk aktivitas mountain bike.

8) Bermain di Children Playground bagi anak-anak

Pengunjung keluarga yang membawa anak-anak dapat memanfaatkan area ini, yang memiliki berbagai fasilitas permainan anak.

2. Aktivitas Wisata Potensial

Analisis pengembangan aktivitas wisata potensial THR Djuanda dilakukan berdasarkan daya tarik potensial yang ada di area kawasan ini, yaitu sebagai berikut:

a. Jalur Wisata Potensial

Terdapat jalur lintas alam berupa jalan setapak yang berada di sekitar area hutan THR Djuanda dengan variasi pemandangan berupa area hutan dan sungai.

b. Sungai

Terdapat potensi pengembangan berupa aliran sungai yang mengalir membelah kawasan THR Djuanda.

c. Kolam PLTA Bengkok

Kolam ini sebenarnya berada di bawah pengelolaan PLTA, tetapi lokasinya masih berada di area THR Djuanda. Kolam ini merupakan kolam buatan untuk kepentingan pembangkit tenaga listrik.

\section{B. Analisis Lingkungan Internal dan Eksternal Kawasan THR Djuanda}

Kawasan THR Djuanda sebagai suatu tujuan wisata memiliki lingkungan internal dan eksternal yang berpengaruh terhadap upaya pengembangan yang dilakukan. Adapun lingkungan internal kawasan mencakup kekuatan dan kelemahan kawasan, sedangkan lingkungan eksternal kawasan mencakup peluang dan ancaman.

1. Lingkungan Internal Kawasan

a. Kekuatan

1) Attraction/ Daya tarik wisata

Berupa atraksi wisata alam dan buatan serta berbagai daya tarik fisik alami yang dimiliki sebagai kawasan Taman Hutan Raya oleh THR Djuanda.

2) Dukungan kebijakan pariwisata daerah

Terdapatnya kebijakan pengembangan pariwisata daerah yang memposisikan THR Djuanda sebagai salah satu objek wisata alam pegunungan yang mendukung tema tema pengembangan tersebut.

3) Letak strategis kawasan 
Merupakan letak strategis kawasan THR Djuanda yang memiliki jarak yang sangat dekat dengan pusat kota Bandung.

4) Aksesibilitas

Merupakan kemudahan akses serta kemudahan pencapaian menuju kawasan THR Djuanda dengan adnya sarana jalan yang sangat memadai yang sangat mendukung kegiatan pariwisata THR Djuanda.

b. Kelemahan

1) Fasilitas pendukung aktivitas wisata belum optimal

Masih terdapat indikasi belum optimalnya fasilitas pendukung aktivitas wisata di sekitar kawasan THR Djuanda, berupa penempatan dan kualitas, yang cenderung dapat berpengaruh negatif terhadap kegiatan pariwisata THR Djuanda.

2) Masih kurang optimalnya aktivitas wisata

Pengembangan aktivitas wisata di THR Djuanda yang belum memanfaatkan potensi daya tarik yang dimiliki secara optimal sehingga menyebabkan aktivitas wisata yang ada menjadi kurang bervariasi dan menyebabkan penurunan kualitas daya tarik THR Djuanda.

3) Pengelolaan

Masih terbatasnya sumber daya manusia bidang kepariwisataan, sehingga menyebabkan pengelolaan kepariwisataan di THR Djuanda menjadi kurang optimal.

2. Lingkungan Eksternal Kawasan

a. Peluang

1) Potensi pengembangan aktivitas wisata

Masih terdapatnya potensi pengembangan, khususnya pengembangan daya tarik yang dimiliki, yang dapat meningkatkan kegiatan pariwisata THR Djuanda.

2) Masyarakat sekitar kawasan

Dukungan masyarakat sekitar kawasan THR Djuanda yang cenderung menanggapi pariwisata THR Djuanda secara positif.

3) Pasar wisata

Merupakan pasar wisata yang berasal dari pasar Kab/Kota Bandung

b. Ancaman dan sekitarnya.

1) Kerusakan lingkungan

Terdapatnya ancaman kerusakan lingkungan dari kegiatan pariwisata, yang dapat menyebabkan deggradasi lingkungan kawasan THR Djuanda.

2) Konflik pengelolaan

Konflik pengelolaan antara pengelola THR Djuanda dengan pengelola ODTW Maribaya, kedua kawasan ini saling berbatasan langsung.Konflik yang terjadi berupa konflik perebutan pemanfaatan area curug Omas. 
Kawasan THR Djuanda dapat diolah dengan matriks SWOT kompetitif, yang dapat dilihat dari blok - blok yang terdapat di kawasan THR Djuanda, yaitu Blok Pakar, Blok Maribaya, dan Blok Dago. Matriks digunakan untuk melihat daya saing blok satu dengan yang lainnya, dengan mengkuantitatifkan aspek terkait melalui rating. Matriks SWOT kompetitif dipegunakan untuk mengetahui posisi daya tarik yang dianalisis, dibandingkan dengan blok-blok lainnya. Diberikan nilai rating yang berbeda berdasarkan pada kondisi blok masingmasing dengan nilai rating: Satu(1) Jika kondisi daya tarik tersebut sangat lemah dibandingkan dengan blok lainnya.Dua(2) Bila kondisinya sedikit lemah dibandingkan dengan blok lainnya.Tiga(3) Bila memiliki kondisi sedikit lebih kuat dibandingakan blok lainnya. Dan tertinggiEmpat(4) Bila memiliki kondisi paling kuat dibandingkan dengan blok lainnya.Penentuan nilai rating blok dilakukan berdasarkan data yang ada. Untuk bobot, dibuat berdasarkan analisis dalam menentukan tingkat kepentingan faktor-faktor strategis daya tarik blok tersebut dengan ketentuan jumlah keseluruhan bobot tersebut yaitu harus sebesar 1,0.

Adapun faktor-faktor strategis yang akan diteliti dari tiap-tiap blok kawasan THR Djuanda diberikan nilai bobot relatif sesuai dengan kekuatan atau keberpengaruhan faktor strategis tersebut terhadap pengembangan, sebagai berikut :

1. Atraksi, akan diberikan nilai bobot sebesar 0,16 dimana faktor ini dilihat berdasarkan jumlah serta kualitas atraksi wisata yang ada.

2. Sarana, diberikan nilai bobot 0,13 dimana faktor strategis ini dilihat dari sisi kelengkapan dan kualitas sarana wisata yang ada.

3. Prasarana, akan diberikan bobot sebesar 0,13 dimana faktor ini akan dilihat dari aspek kelengakapan dan kualitas prasarana yang ada.

4. Aksesibilitas, akan diberikan nilai bobot 0,13 dimana faktor ini dilihat dari aspek kemudahan pencapaian serta dilihat dari kualitas sarana akses yang ada.

5. Pasar Wisata, diberikan nilai bobot o,13 dimana faktor ini dilihat dari aspek kecendrungan kepopuleran dari lokasi.

6. Bentang Alam, diberikan nilai bobot sebesar o,10 dimana faktor ini akan dilihat dari aspek keindahan, kebersihan, kualitas lingkungan serta pencemaran yang terjadi.

7. Ragam aktivitas, diberikan nilai bobot 0,11 dimana faktor ini dilihat dari aspek ragam aktivitas serta kendala beraktivitas.

8. Potensi pengembangan, diberikan nilai bobot 0,13 dimana faktor ini dilihat dari aspek luas lahan dan aspek kemungkinan pengembangan daya tarik yang ada. 


\begin{tabular}{|c|c|c|c|c|c|c|c|c|c|}
\hline \multirow{2}{*}{ No } & \multirow{2}{*}{$\begin{array}{l}\text { Faktor } \\
\text { Strategis }\end{array}$} & \multirow{2}{*}{ Bobot } & \multicolumn{2}{|c|}{ Blok A } & \multicolumn{2}{|c|}{ Blok B } & \multicolumn{2}{|c|}{ Blok C } & \multirow{2}{*}{-Keterangan Rating } \\
\hline & & & Rating & $\begin{array}{l}\text { Bobot } \\
\text { Skor }\end{array}$ & Rating & $\begin{array}{l}\text { Bobot } \\
\text { Skor }\end{array}$ & Rating & $\begin{array}{l}\text { Bobot } \\
\text { Skor }\end{array}$ & \\
\hline 1 & Atraksi wisata & 0,16 & 4 & 0,64 & 3 & 0,48 & 2 & 0,32 & $\begin{array}{c}\text { Jumlah dan kualitas } \\
\text { atraksi yang ada } \\
\text { Dilihat dari }\end{array}$ \\
\hline 2 & Sarana & 0,13 & 4 & 0,52 & 3 & 0,39 & 2 & 0,26 & $\begin{array}{c}\text { kelengkapan dan } \\
\text { kualitas sarana } \\
\text { Dilihat dari }\end{array}$ \\
\hline 3 & Prasarana & 0,13 & 3 & 0,39 & 4 & 0,52 & 2 & 0,26 & $\begin{array}{l}\text { kelengkapan dan } \\
\text { kualitas prasarana } \\
\text { Dilihat dari }\end{array}$ \\
\hline 4 & Aksesbilitas & 0,13 & 4 & 0,52 & 2 & 0,26 & 3 & 0,39 & $\begin{array}{c}\text { kemudahan } \\
\text { pencapaian dan } \\
\text { kualitas sarana akses }\end{array}$ \\
\hline 5 & Pasar wisata & 0,11 & 4 & 0,44 & 3 & 0,33 & 2 & 0,22 & $\begin{array}{c}\text { Dilihat dari } \\
\text { kecendrungan } \\
\text { kepopuleran lokasi } \\
\text { Dilihat dari }\end{array}$ \\
\hline 6 & Bentang alam & 0,10 & 3 & 0,30 & 4 & 0,40 & 2 & 0,20 & $\begin{array}{c}\text { keindahan, } \\
\text { kebersihan,kualitas } \\
\text { lingkungan serta } \\
\text { pencemaran yang } \\
\text { terjadi }\end{array}$ \\
\hline 7 & Ragam aktivitas & 0,11 & 4 & 0,44 & 3 & 0,33 & 2 & 0,22 & $\begin{array}{l}\text { Dilihat ragam dan } \\
\text { kendala beraktivitas }\end{array}$ \\
\hline 8 & $\begin{array}{c}\text { Potensi } \\
\text { pengembangan }\end{array}$ & 0,13 & 4 & 0,52 & 3 & 0,39 & 2 & 0,26 & $\begin{array}{c}\text { Dilihat dari luas lahan } \\
\text { dan kemungkinan } \\
\text { pengembngan daya } \\
\text { tarik }\end{array}$ \\
\hline & Jumlah Total & 1 & & 3,77 & & 3,10 & & 2,13 & $\begin{array}{l}\text { Ranking: } \\
\text { Blok Pakar } \\
\text { Blok Maribaya } \\
\text { Blok Curug Dago }\end{array}$ \\
\hline
\end{tabular}

\section{RATING BLOK THR DJUANDA BERDASARKAN MATRIKS SWOT KOMPETITIF}

Dengan melihat hasil analisis matriks SWOT kompetitif di atas maka dapat disimpilkan bahwa blok Pakar berada pada rangking pertama, dimana blok Pakar ini secara umum memiliki keunggulan faktor-faktor strategis, dan memiliki peluang yang paling besar untuk dikembangkan kegiatan wisata. Selain itu, pada tingkat rangking kedua adalah blok Maribaya dimana dari rating faktor-faktor strategis blok ini dapat dikatakan bahwa potensi pengembangan blok ini berada di bawah potensi blok Pakar, dan berada di atas potensi pengembangan blok curug Dago. Sedangkan blok curug Dago diketahui memiliki karakter faktorfaktor startegis yang cenderung lebih kecil dari dua blok lainnya.

\section{PENUTUP}

\section{Kesimpulan}

THR Djuanda memiliki beragam potensi daya tarik wisata. Berdasarkan hasil analisis maka dapat disimpulkan bahwa secara umum dapat dikatakan bahwa aspek elemen alam dan daya tarik THR Djuanda, memiliki kondisi yang 
dapat mendukung terhadap pengembangan wisata yang akan dilakukan, karena memiliki karakter sifat yang mendukung pengembangan, baik aktivitas wisata, maupun fasilitas pendukung aktivitas wisata.

Secara umum atraksi wisata yang tersebar di tiga blok yang terdapat di kawasan ini, selain itu menurut hasil analisis dapat diketahui bahwa blok Pakar merupakan kawasan yang memiliki potensi pengembangan yang sangat besar dibanding dengan blok-blok lainnya di THR Djuanda dilihat dari daya saing faktor strategis kawasan yaitu faktor jumlah serta kualitas atraksi wisata yang ada, sisi kelengkapan, kualitas sarana dan prasarana yang ada,aspek kemudahan pencapaian serta dilihat dari kualitas sarana akses yang ada, aspek kecendrungan kepopuleran dari lokasi, aspek keindahan, kebersihan, kualitas lingkungan, pencemaran yang terjadi, aspek ragam aktivitas serta kendala aktivitas, aspek luas lahan dan aspek kemungkinan pengembangan daya tarik yang ada, sehingga potensi pengembangan wisata cenderung lebih dapat dilakukan di kawasan blok Pakar THR Djuanda.

Selain itu, bila melihat kepada pengembangan aktivitas wisata yang sudah dilakukan THR Djuanda, secara umum aktivitas wisata ini masih memerlukan pengembangan lebih lanjut dan lebih mengoptimalkan aktivitas wisata yang ada itu sendiri, serta berdasarkan karakteristik daya tarik yang didapat, maka di kawasan ini memiliki peluang besar untuk dikenbangkan aktivitas baru dalam mendukung perannya sebagai ragam pilihan aktivitas wisata bagi pengunjung, terutama pengembangan aktivitas wisata apresiatif yang dapat memberikan apresiasi pengunjung terhadap kawasan, serta aktivitas rekreasi bagi pengunjung, dimana aktivitas wisata ini bertujuan untuk mengoptimalkan pengalaman berkunjung, diamana pengembangan aktivitas wisata ini dapat dilakukan terhadap aktivitas wisata aktual yang sudah ada.

\section{Saran}

1. Pedoman/Arahan Umum Pengembangan Aktivitas wisata.

Dalam melakukan pengembangan aktivitas wisata di THR Djuanda diperlukan pedoman/aturan/batasan pengembangan yang harus dipenuhi, sehingga pengembangan yang dilakukan dapat sesuai fungsi dari THR Djuanda.

a. Pengembangan harus berwawasan lingkungan

Harus dicapai suatu keseimbangan antara kebutuhan aktivitas wisata dengan kemampuan lingkungan sekitar alam pengembangan aktivitas wisata di THR Djuanda. Pengembangan yang dilakuakan tidak boleh mendegradasikan sumber daya yang ada serta ramah lingkungan.

b. Pengoptimalan pengalaman pengunjung

Pengembangan aktivitas wisata yang baik dapat memberikan pengalaman yang baik pula terhadap pengunjung, dimana aktivitas tersebut selain dapat bermuatan wisata dan rekreasi juga dapat memiliki nilai-nilai yang dapat menciptakan apresiasi pengunjung terhadap perlindungan dan pelestarian kawasan serta meningkatkan kesadaran dan kecintaan terhadap sumber daya.

c. Keterlibatan masyarakat sekitar 
Pengembangan aktivitas wisata di THR Djuanda sedapat mungkin dapat memberikan keuntungan ekonomi bagi masyarakat sekitar dengan melakukan dan melibatkan masyarakat secara aktif dalam kegiatan wisata di THR Djuanda.

d. Activity clustering

Tidak menempatkan aktivitas wisata yang tidak sesuai satu sama lainnya/bertentangan sifatnya dalam satu area yang sama/berdekatan, untuk menghindari bentrok kepentingan.

e. Pengembangan fasilitas pendukung aktivitas wisata dengan prinsip sebagai berikut:

1) Desain, lokasi dan penataan fasilitas harus harmonis dan mempertimbangkan lingkungan sekitar seperti pertimbangan proporsi, pewarnaan dan bahan baku.

2) Pertimbangan kesesuaian jenis, bentuk, serta fungsi fasilitas dengan lingkungan sekitar.

3) Pertimbangan keseimbangan antara kebutuhan pengalaman wisata/rekreasi dengan kualitas lingkungan.

4) Pemanfaatan bahan baku serta karakter budaya lokal.

5) Pemusatan fasilitas.

2. Pengembangan Aktivitas Wisata

Pengembangan aktivitas wisata di THR Djuanda dapat dilakukan terhadap aktivitas wisata aktual yaitu aktivitas yang sudah ada di THR Djuanda serta aktivitas potensial.

a. Aktivitas Wisata Aktual

Aktivitas wisata yang dapat dilakukan di THR Djuanda terdiri dari aktivitas luar ruangan (outdoor activity) dan dalam ruangan (indoor activity). Rekomendasi pengembangan aktivitas wisata aktual luar ruangan dapat dilakukan dengan mengikuti arahan sebagai berikut:

1) Mengamati Goa

Pengembangan fasilitas penerangan goa ini harus dilakukan dengan memperhatikan dari bentuk goa dan tidak mengurangi kualitas dari daya tarik goa. Untuk menghasilkan suasana yang lebih natural maka harus dilakukan pemasangan penerangan tradisional berupa obor, dimana selain dapat menarik juga dapat memberi kesan berbeda dari atraksi wisata sejenis.

2) Mengamati fenomena alam

Berdasarkan analisis maka pengembangan aktivitas pengamatan air terjun ini dapat diprioritaskan terhadap area curug lalay yang berada diarea blok Pakar. Pertimbangan hal ini dikarenakan curug Omas dan curug Dago relatif sudah dikembangkan lebih dulu, selain itu daya tarik curug Lalay lebih beragam sehingga pengembangan dapat diprioritaskan pada area curug Lalay. Selain itu yang harus disediakan adalah papanpapan informasi baik berisi peringatan atau aturan selama melakukan kunjungan.

3) Aktivitas mengamati flora di arboretum 
Pengembangan yang harus dilakukan untuk meningkatkan kualitas pengalaman beraktivitas pengunjung terkait dengan aktivitas mengamati flora adalah meningkatkan kualitas fasilitas papan nama latin/daerah yang tertempel pada pohon di area arboretum.

4) Rekreasi di alam terbuka sambil menikmati panorama alam

Walaupun aktivitas ini dinilai sudah cukup baik karena letaknya yang berada di area pemusatan pengunjung dan berdekatan dengan berbagai fasilitas umum seperti toilet, tetapi perlu dilakukan fasilitas pendukung sarana tempat cuci tangan (washtafel) dan penambahan sarana tempat sampah disekitar area tersebut.

5) Berjalan di alam/jogging dan Mountain Bike

Pengembangan yang harus dilakukan untuk meningkatkan kualitas aktivitas wisata ini adalah berupa penyediaan fasilitas berupa papan peringatan terhadap pengunjung untuk berhati-hati agar tidak terjadi bentrok antar dua aktivitas yang berbeda, karena terdapat dua aktivitas yang dapat dilakukan yaitu berjalan kaki dan bersepeda.

6) Aktivitas bermain di Children Playground

untuk meningkatkan aktivitas wisata yang bisa dilakukan, peru dilakukan pengembangan aktivitas wisata terutama pada area kosong berupa pengadaan aktivitas adventure games bertema low rope element khusus untuk anak-anak seperti flying fox, spider web, jembatan tali dan panjat tebing mini didalam area Children Playground yang bertujuan utuk menambah pengembangan aktivitas wisata aktual, dalam ruangan dapat dilakukan sebagai berikut:

7) Mengamati koleksi yang ada di museum THR Djuanda

Seperti sudah diketahui bahwa secara umum aktivitas ini dapat dikatakan sudah cukup baik karena bermuatan pendidikan dan memiliki fasilitas bangunan museum.

8) Mengamati tanaman

Aktivitas ini termasuk kedalam salah satu jenis aktivitas pengamatan flora yang dinilai sudah cukup baik dengan pertimbangan bahwa aktivitas ini sangat bermuatan pendidikan bagi pengunjung.

b. Aktivitas Wisata Potensial

1) Aktivitas Wisata di sekitar area Kolam PLTA Bengkok

Dengan melihat pada potensi yang ada, maka direkomendasikan pengembangan aktivitas wisata berbasis air / waterbased activity disekitar area kolam PLTA Bengkok yang memiliki area kolam seluas kurang lebih $3000 \mathrm{M}$, dengan melakukan kerjasama saling menguntungkan dengan pihak PLTA Bengkok untuk memberikan ragam aktivitas wisata, terutama aktivitas wisata rekreasi bagi pengunjung.

Aktivitas yang dapat dikembangkan adalah seperti berperahu kayuh yang dibedakanuntuk dewasa dan anak-anak.

2) Aktivitas Wisata di sekitar sungai Cikapundung

Dengan melihat potensi yang ada, maka pengembangan aktivitas yang dapat dikembangkan di area sungai ini berupa aktivitas wisata bebasis air/water based activities yang memanfaatkan aliran air sungai. 
Aktivitas yang dikembangkan dapat beupa aktivitas berperahu karet/arung jeram yang dikhususkan bagi pengunjung dewasa.

3) Aktivitas Jalur Lintas Alam

Dengan melihat kepada daya tarik berupa jalan setapak tanah yang relatf belim diketahui oleh kebanyakan pengunjung, maka berpotensi dikembangkan aktivitas nature tracking pada jalur lintas alam yang sudah tersedia berupa jalan setapak berbahan tanah dengan lebar 0,5 meter- 1 meter yang melewati area hutan dan menyusuri sungai THR Djuanda sejauh kurang lebih 2,5 Km.

4) Aktivitas wisata perkebunan

Seperti sudah diketahui bahwa pada area sekitar kawasan terdapat lahan enclave penduduk yang saat ini dimanfaatkan untuk area perkebunan. Perlu dilakukan pengembangan aktivitas yang dapat dilakukan pengunjung seperti membeli hasil kebun yang berada di kawasan THR Djuanda.

3. Pengembangan Fasilitas

Pengembangan fasilitas pendukung aktivitas wisata di THR Djuanda ini akan dilakukan berdasarkan konsep fasilitas yang dikemukakan bovy 1998, dengan mengacu pada konsep tersebut maka dapat diketahui kekurangan fasilitas yang ada di THR Djuanda.

a. Akomodasi

Seperti sudah diketahui bahwa belum terdapatnya fasilitas akomodasi si sekitar kawasan THR Djuanda, oleh karena itu pengembangan fasilitas akomodasi yang dapat sesuai dengan tema pengembangan perlu dilakukan untuk mengantisipasi kebutuhan akomodasi pada pengunjung.

Pasar yang dituju oleh pengembangan ini adalah orang yang ingin menyewa akomodasi berbentuk rumah ataupun villa.

b. Food services and shopping

Perlu dilakukan pemusatan penempatan kios makan-minum ke lokasi yang berdekatan dengan area pemusatan pengunjung.

Selain itu perlu perlu juga diadakan fasilitas aktivitas bebelanja cinderamata, berupa kios-kios cinderamata.

c. Fasilitas pendukung dan infrastruktur

1) Peningkatan kualitas fasilitas meja taman dan tempat duduk, karena terdapat beberapa fasilitas meja taman dan tempat duduk yang rusak dan perlu diperbaiki.

2) Penambahan fasilitas papan petunjuk baik peringatan maupun petunjuk arah pada beberapa lokasi tertentu yang memiliki fasilitas ini terutama pada area pengembangan aktivitas wisata yang baru.

3) Peningkatan kualitas fasilitas jalan setapak berbahan tanah untuk aktivitas wisata nature tracking berupa pembuatan anak tangga pada jalan yang dirasa perlukan pada jalan yang menanjak dan menurun.

4) Tempat parkir utama perlu dijadikan sebagai area pemusatan fasilitas umum yang berisikan fasilitas toilet, kios cinderamata dan makanminum, serta fasilitas ibadah karena area parkir utama dapat 
dikatagorikan sebagai area pemusatan pengunjung dan memiliki daya dukung yang tinggi.

5) Pengadaan fasilitas spot pengamatan pada area-area tertentu yang memiliki kualitas lingkungan yang baik, serta dekat dengan atraksi wisata.

4. Pengelolaan

Untuk meningkatkan kegiatan priwisata di kawasan THR Djuanda, maka perlu struktur organisai pengelola THR Djuanda, sehingga pelaksanaan kegiatan pariwisata dapat dilakukan/berjalan lebih maksimal pada pengelolaan wisata kawasan THR Djuanda.

\section{DAFTAR PUSTAKA}

A. Gunn, Clare. 1994. Tourism Planning: Basic Concepts Cases. USA. Taylor and Francis.

Bovy, Manuel and Lawson, Fred. 1998. Tourism and Recreation Handbook of Planning and Design. UK: Butterworth-Heinemann.

Ceballos-Lascurain, Hector. 1996. Tourism, Ecotourism, and Protected Areas. IUCN, Cambridge: UK

Fandeli, Chafid. 2002. Perencanaan KepariwisataanAlam. Fakultas Kehutanan. Yogyakarta. Universitas Gajah Mada.

Gold, Seymour M. 1980. Outdoor Recreation Planning. McGraw-Hill: USA.

Gunn, Clare. 1972. Vacationscape: Designing Tourist Regions. The University of Texas at Austin. Bureu of Bussiness Research

Hasan, Iqbal. 2002. Pokok-Pokok Materi Metologi Penelitian dan Aplikasinya. Jakarta. Ghalia Indonesia.

Inskeep, Edward. 1991. Tourism Planning: An Integrated and Sustainable Development Approach. New York. Van Nostrand Reinhold.

Jubenville, Alan. 1976. Outdoor Recreation Planning. Philadelphia, USA. W.B. Saunder Company

Lawson, Fred dan Manuel Baud Bovy. 1998. Tourism and Recreation Handbook of Planning and Design. London.Butterworth-Heneman.

McCool, Stephen F. 2002. Tourism, Recreation and Sustainability: Linking Culture and the Environment.. UK. Biddles Ltd. Guildford and King Lyna.

McIntosh, Robert W., et all. 1995. Tourism: Principles, Practices, Philosophies. $7^{\text {th }}$ Edition. Canada: John Wiley \& Sons Inc.

Nazir, Moh. 2003. Metodologi Penelitian. Jakarta. Gramedia Pustaka Utama.

www.dephut.go.id 